Discussion

\title{
Road Safety Education in the Context of the Sustainable Development of Society: The Romanian Case
}

\author{
Gabriel Brătucu, Anca Madar, Dana Boşcor *, Codruţa Adina Băltescu and \\ Nicoleta Andreea Neacşu \\ Faculty of Economic Sciences and Business Administration, Transilvania University of Braşov, \\ str. Colina Universitatii, nr. 1, Building A, Braşov 500036, Romania; gabriel.bratucu@unitbv.ro (G.B.); \\ ancamadar@unitbv.ro (A.M.); codruta.baltescu@unitbv.ro (C.A.B.); deea_neacsu@yahoo.com (N.A.N.) \\ * Correspondence: dana.boscor@unitbv.ro; Tel.: +40-723-486-444 \\ Academic Editors: Ralf Hansmann and Marc A. Rosen \\ Received: 20 January 2016; Accepted: 14 March 2016; Published: 16 March 2016
}

\begin{abstract}
The increased number of road accidents, leading to deaths and serious injuries is a social problem facing most of the world countries, which can affect the sustainable development of a society. This has economic implications, because it impacts the increase of expenditure on hospitalization and the recovery costs of those injured. The current article is based on a quantitative research, coordinated by the authors, conducted among traffic participants from Romania. The major objective of the study was to quantify the main aspects of seatbelt wearing behavior. The research was carried out at national level and used a systematic probabilistic sampling. The sample contains 4346 subjects, of which 3120 were from the automobile section, representing the topic of this article, and being representative of the Romanian adult population. The main research results showed that the percentage of women always wearing seatbelts $(76.4 \%)$ is higher than the percentage of men $(69.9 \%)$. Additionally, the highest percentage of people always wearing seatbelts is found at the age group over 55 years $(85.2 \%)$. The percentage decreases with age- the age group 18-25 are the least likely to wear seatbelts.
\end{abstract}

Keywords: sustainable development; quantitative market research; seatbelt; road traffic accidents; traffic behavior

\section{Introduction}

Sustainability is a duty that concerns organizations and political entities. Sustainability practices are related to lower expenditures and focuses on constructing a community in which an appropriate equilibrium is brought about between economic, social, and ecological targets [1]. It is widely accepted that most instances of deteriorating environmental conditions are caused by human behavior [2].

Road safety is considered a major issue of public health, both at a global level, and in Romania. In terms of transport, both in Romania and the EU, road transport has the largest share of transportation types. It consumes the greatest amount of energy, surpassing air, rail or inland waterway transport by far [3]. The social and economic implications of road safety can affect the sustainable development of countries. The convenience of the automobile has implications for highway safety outcomes and public policy. There are also associated societal problems in the form of highway accidents with greater cost burdens on the health system [4]. Highway traffic accidents cause internal costs, directly (e.g., loss of lives and property damage,) and external costs, indirectly, (e.g., travel time delay, energy consuming, and air pollution emission) [5].

Alcohol or drug consumption, exceeding the legal speed limit, generate between $30 \%$ and $50 \%$ of road accidents. Those and the refusal to wear the seatbelt are the major causes of road accident mortality in the EU [6,7]. A report of the European Transports Safety Council (ETSC) shows that in 
the period between 2001 and 2010, the number of deaths from road accidents at EU level dropped by $43 \%$. The highest reductions were recorded in the Baltic states, approximately $60 \%$, while the lowest was in Romania, only 3\%. The average fatality risk in the Southern, Central, and Eastern European countries—-the "SEC Belt countries" - is about three times higher than the EU average [8]. 2013 was the second consecutive year which showed a significant drop in the number of people killed on the highways of Europe. The number of road fatalities has decreased by $8 \%$ compared to 2012, following the $9 \%$ decrease between 2011 and 2012 [9].

2014 statistics showed a significant decrease in the previous two years in the number of people killed on European roads, but the decrease slowed considerably in 2014-the number of deaths decreased by only $1 \%$ compared to 2013 [10]. In 2013, 25,700 deaths on the road were recorded in the EU [10]. Although this means a drop of 5700 persons in relation to 2010, almost 70 persons still die each day on EU highways. According to estimations of the World Health Organization, the cost of road accidents represents between 1\% and $2 \%$ of the EU's yearly GDP [10]. In the year 2014, ETSC published a study on the number of children who died in car accidents in the EU [11]. It showed that in the year 2012, at least 319 children, aged 0 to 14, who were passengers in automobiles died. Many others were seriously injured. Among the recommendations of the ETSC for the reduction of the number of persons killed or seriously injured in road accidents are: the tightening of legislative measures regarding seatbelts use and child safety seats, awareness campaigns educating parents about the importance of child safety systems, and increasing the accessibility of child safety systems by reducing VAT in compliance with EU norms regarding VAT on "essentials products".

By educating citizens, especially the young within the schooling system, we aim to play a key role in supporting sustainable development and securing a sustainable future for the next generations [2].

The research presented in this article is the first complex quantitative study carried out in Romania on this topic. The results are already used by the Romanian Police General Headquarters in the strategic approach of the new Road Code entered into force in 2015. Moreover, the study shows the need of rethinking the prevention programs. The new national strategy regarding road education must include these programs, which will lead to positive effects in Romania in the long term from the social and economic point of view.

The primary objectives of the research were:

- Identifying the reasons behind wearing/not wearing the seatbelt;

- Setting situations of wearing/not wearing the seatbelt;

- Quantify the degree of wearing/not wearing the seatbelt by the driver's passengers.

- Identifying the degree to which drivers or their passengers were sanctioned for not wearing the seatbelt.

Understanding the extent to which drivers are aware of the risks of not wearing the seatbelt.

\section{Literature Review}

Romania is the EU member states with the second highest mortality rate from road accidents [10]. In 2014, Romania reported approximately 91 deaths per million residents, far exceeding the EU average of 51 deaths [10]. Romania is slowly reducing its gap in relation to the safer EU member states. Between 2010 and 2014, the rate of road deaths in Romania dropped by $24 \%$, compared to the average decrease of $18 \%$ at EU level. In Romania, the most important indicators of the dynamics of serious car accidents confirm the maintenance of the downward trend of the road risk recorded at national level. The reductions were compared to the year 2008, a benchmark year for the number and consequences of this type of events, representing $13 \%$ of the total number of serious accidents, $34.2 \%$ of deaths, $7.15 \%$ of the seriously injured people and $4.4 \%$ of slightly injured from serious accidents. This important reduction in the road risk is shown in the last Annual Road Safety Performance Index (PIN) report of the ETSC, showing the progress Romania made in the field of road safety, from 142 deaths per million 
residents in 2008, to 91 deaths per million residents at the end of 2014 [8]. Figure 1 shows the dynamic evolution of road traffic injury accidents in the period 2005-2014 in Romania [12].

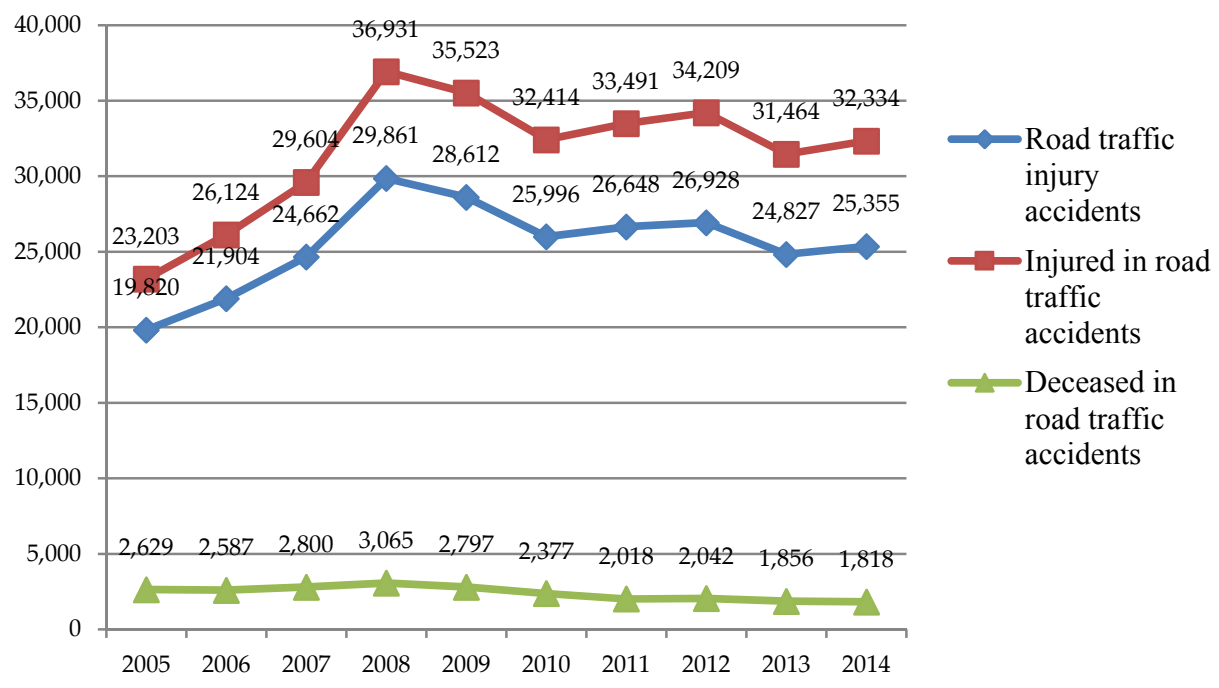

Figure 1. Dynamic evolution of road traffic injury accidents in the period 2005-2014 in Romania.

According to the Romanian Police General Headquarters, the main causes triggering serious road accidents are reckless driving, illegal overtaking, illegal speed, pedestrians' lack of discipline, and not giving way to pedestrians or other vehicles. Passengers not wearing seatbelts represents an important death factor caused by road accidents. Article 36 of the new road code states: "the drivers and passengers occupying seatbelts provided seats or approved safety devices must wear those while driving on public roads, with the exception of cases provided in regulations" [13]. Additional studies focus on the factors seeking to explain reasons for wearing or not the seatbelt [14-18].

The probability of deaths in car accidents is 2.34 times higher for the drivers who do not wear the seatbelt than for those who wear it [19], and $97 \%$ of those involved in accidents with fatal consequences do not wear the seatbelt [14]. Additionally, $95 \%$ of those who were wearing seatbelts did not suffer injuries in road accidents, while $37 \%$ of those driving with the seatbelt fastened were injured [20]. Fastening the seatbelt in traffic is influenced by the passengers' position in the vehicle. Although wearing the seatbelt is mandatory for front seat passengers in all European Union States, not all the persons comply with the law. A survey in Belgium, France, Germany, Italy, Romania, Spain, and the UK also showed that people in Romania were the most likely to travel in the rear seats without a seatbelt ( $84 \%)$, followed by Italy (56\%) and Spain (39\%) [21].

There are important differences in wearing the seatbelts between regions and countries [22]. In Norway, for example, it was highlighted that the seatbelt was used to a high extent, namely $93.5 \%$, in 2008 [23]. The use of the seatbelt by front seat passengers prevents the death of those involved in road accidents by $45 \%-60 \%$ and reduces the seriousness of injuries in $50 \%-65 \%$ of the cases [24]. Occupant ejection and the lack of seatbelt use dramatically increased the occupants' risk for all types of injury in rollover crashes. Seatbelt use decreased the rate of partial ejection by a factor of 2.6 (from $5.6 \%$ to $2.2 \%$ ) and virtually eliminated complete ejection, reducing it by a factor of 180 (from $17.6 \%$ to $0.1 \%$ ) [25]. The concerns regarding the reduction of the number of deaths and seriously injured persons in road accidents have determined the performance of some studies, which showed the existing differences between wearing the seatbelt by the driver and the vehicle's passengers by gender and age, and other features which revealed the factors that influence road users' behavior regarding seatbelt wearing. It has been observed that wearing seatbelts is also influenced by other socio-demographic factors, such as marital status, education level, type of vehicle [16,26-28], the compulsory nature of seatbelt wearing stipulated in the legislation [18], the duration of the drive, the annual distance, the place of residence 
(urban/rural), the driver being a professional or an amateur [15,29], political orientation, religion, and income [30].

The purchase of a vehicle is extensively influenced by the presence of safety features (seatbelts, airbags, antilock breaking systems-ABS, electronic brakeforce distribution-EBD). In Sweden and Spain, it has been shown that safety features are the most important factor in the car purchase decision [31]. The results obtained revealed that safety features are more valuable in comparison to crashworthiness or crash test results when evaluating a vehicle for safety, though the way respondents valued different attributes varied by country [31]. Sustainable development is a goal that can only be achieved by changing behavior [32]. The action of that behavior can work at different levels of the society from the individual personal life style, to political decision-making, or business closures, etc., which have different degrees of powers in making a difference for sustainable development [32].

In order to reduce the loss of human lives, the international, European, and national authorities have initiated a series of programs for prevention through the education of participants in traffic and focusing, in particular, on primary and secondary school pupils, as future participants in traffic. Creating an understanding of the structure of sustainability education is needed to address the challenges in this field [33]. The European Program of Action for Road Safety 2011-2020 (MEMO/10/343) establishes challenging plans for halving the number of deaths in road accidents in 10 years. It contains ambitious proposals which focus on improving vehicles and infrastructure, and also the behavior of participants in traffic [9]. An initiative of the European Commission is the European Handbook for Road Safety, which has the goal of supporting any type of initiative for raising traffic safety which are or will be introduced by member states [34]. The European Observatory for Road Safety and the EU data base CARE (Community Road Accident Database) are two important platforms of knowledge consolidation which collect scientific data on safety in traffic and make it publicly available. In Romania, the Inter-ministerial Council for Road Safety and the Dori Slosberg Foundation Romania have initiated the Road Agenda project, ensuring an interactive platform of communication and promotion of educational activities in the domain of road safety unfolding at a national level [35].

\section{The Objectives and the Research Method Used}

The current research was carried out with the help of the company Profiles International Romania, which provided the necessary logistics ( interviewers, creating the database with the SPSS software) and the help of the Romanian Police General Headquarters, which provided the police crew throughout the country. The research was conducted at the national level, questionnaires being applied in the entire country, including the capital, Bucharest.

The present quantitative research is aimed at defining and assessing relevant aspects of the research identified by qualitative research methods, using the systematic probabilistic sampling. The systematic probabilistic sampling involves a random selection of a starting number, to which a fixed, predetermined amount is added, resulting in a sample unit (in this research the statistical step established was 10). It is a simple procedure, efficient, and easy to achieve, which is frequently used in research studies. The police crew, after being trained for the study, stopped every tenth car on the established direction of movement. The policemen were trained not to influence the subjects' answers through their verbal or nonverbal behavior, by keeping an adequate distance, which ensures the confidentiality of the answers. For each location of information collection two teams of two interviewers were used, which engaged during three consecutive hours. In each county the most favorable locations were identified based on traffic intensity. Information collection lasted one week and the operators have interviewed the subjects in hourly periods in different locations, to ensure the estimated representativety.

After centralizing the questionnaires filled in by the traffic participants and after checking them, a final sample resulted, comprising 4346 valid questionnaires, of which 3120 represented the car section, with the margin statistical error of $\pm 1.75 \%$. 
The questionnaire used contained 41 questions and five sections: introduction, car section, minibuses and buses section, vans/tractors/trucks section, and motorcycle section.

The car section covered in this article contained 10 questions, four questions from the introduction, and two identification questions, namely age and gender (see Table 1). It must be mentioned that, in this research, gender and age were not solid sampling criteria. For example, in the case of gender, the statistical data held by the Romanian Police General Headquarter, shows that men represent $65 \%$ of the car drivers in Romania and 95\% of minibuses and buses drivers. For these reasons, there is no gender balance as the sample was designed to be representative at the level of the researched population-e.g., adult person car drivers. The subjects interviewed were only those driving the cars stopped in traffic, according to the sampling method, and the questions regarding the passengers were also answered by the drivers and not by the passengers. Moreover, the random sampling method used has shown the existence of such imbalances through the structure on age and gender of the final sample (see Table 2). Taking into account these caveats there was no need to validate and recover the final sample, which did not affect its representativity.

Table 1. Content of the questions included in the questionnaire for showing the Romanian car drivers' behavior regarding the seatbelt use in the traffic.

\begin{tabular}{lc}
\hline \multicolumn{1}{c}{ Content of the Questions } & Number of Questions \\
\hline Regular seatbelt use by the driver & 1 \\
\hline $\begin{array}{l}\text { Which are the moments in traffic when drivers do not fasten the seatbelt } \\
\text { and the reasons of this behavior }\end{array}$ & 2 \\
\hline The degree of fastening the seatbelt for the car passengers & 2 \\
\hline The conditions in which passengers under 3 years old are transported & 3 \\
\hline $\begin{array}{l}\text { Which are the risks and penalties for the car drivers and the passengers } \\
\text { when they do not use the seatbelt }\end{array}$ & 1 \\
\hline $\begin{array}{l}\text { Equipping the car with seatbelts } \\
\text { General questions regarding how long drivers have been holding the } \\
\text { driving license, the type of roads and the periods during the day when } \\
\text { most travels are made, the average distance of a daily travel }\end{array}$ & 4 \\
\hline \begin{tabular}{l} 
Gender and age \\
\hline
\end{tabular}
\end{tabular}

The main objective of this research was to quantify the main aspects of seatbelt wearing behavior while driving. In this respect, information was collected regarding:

(1) The number of drivers who wear the seatbelt in the traffic by age and gender.

(2) The number of passengers who wear the seatbelt in the traffic by driver age and gender.

(3) The number of drivers fined for not wearing the seatbelt in the traffic, by age and gender.

(4) The situations in which drivers do not wear the seatbelt in traffic, by age and gender.

(5) The reasons why drivers do not wear the seatbelt in traffic.

Afterwards, $20 \%$ of the interviewed subjects were followed up by telephone interviews. They aimed to ensure that the interviews were effectively achieved and correctly performed (the behavior of the operators was according to the training, not influencing the recorded answers).

Table 2 presents the descriptive features of the researched sample.

The 41 Romanian counties were equally represented in the sample, and for Bucharest, Romania's capital, a higher number of questionnaires was allocated as a higher number of vehicles transit through the area. 
Table 2. Descriptive information of survey participants.

\begin{tabular}{lcc}
\hline & N & $\%$ \\
\hline Gender & & \\
\hline - Men & 2539 & 81.4 \\
- Women & 581 & 18.6 \\
\hline Age & & \\
\hline - $18-25$ years & 514 & 16.5 \\
- 26-35 years & 948 & 30.4 \\
- 36-45 years & 910 & 29,2 \\
- 46-55 years & 444 & 15.6 \\
- Over 55 years & 304 & 9.7 \\
\hline The Period of Holding the Driving License & & \\
\hline - More than 10 years & 1803 & 57.8 \\
- 6-10 years & 605 & 19.4 \\
- 3-5 years & 449 & 14.4 \\
- 1-2 years & 179 & 5.7 \\
- Less than 1 year & 84 & 2.7 \\
\hline Which is the Period of the Day when People Drive Most & & \\
\hline - Only during the day & 1170 & 37.5 \\
- Especially during the day & 1828 & 58.6 \\
- Especially during the night & 100 & 3.2 \\
- Only during the night & 22 & 0.7 \\
\hline
\end{tabular}

\section{Results}

After analyzing the answers, it was noticedthat $71,1 \%$ of the subjects always wear the seatbelt. Additionally, a percentage of $2.2 \%$ never use the seatbelt. Taking into account the gender, the percentage of women who wear seatbelts is always higher $(76.4 \%)$ than men in the same situation $(69.9 \%)$. The percentage of women who never wear the seatbelt when driving the car is lower $(1.4 \%)$ than that of men $(2.4 \%)$. It can be concluded that women tend to obey the law regarding wearing the seatbelt to a higher extent, having a preventive attitude (see Table 3 ).

Table 3. Wearing the seatbelt when driving the car by driver gender and age.

\begin{tabular}{lcccc}
\hline & \multicolumn{4}{c}{ The Frequency of Fastening the Seatbelt in Traffic (\%) } \\
\cline { 2 - 5 } & Never & Sometimes & Seldom & Always \\
\hline Gender: & \multicolumn{5}{c}{} \\
\hline men & 2.4 & 11.9 & 15.8 & 69.9 \\
women & 1.4 & 10.0 & 12.2 & 76.4 \\
Total & 2.2 & 11.5 & 15.2 & 71.1 \\
\hline Age: & & & & \\
\hline 18-25 years & 2.1 & 15.8 & 17.1 & 65.0 \\
26-35 years & 3.4 & 14.2 & 16.8 & 65.6 \\
36-45 years & 1.4 & 10.5 & 15.6 & 72.4 \\
46-55 years & 2.0 & 7.7 & 12.4 & 77.9 \\
over 55 years & 1.0 & 4.3 & 9.5 & 85.2 \\
Total & 2.2 & 11.5 & 15.2 & 71.1 \\
\hline
\end{tabular}

Taking into account age (see Table 3), it can be noticed that the highest percentage of those who never wear seatbelts when driving the car is represented by respondents in the age range 26-35 years $(3.4 \%)$, with this percentage decreasing with older respondents, $1.4 \%$ for the age range $36-45$ years, and $1 \%$ for the group over 55 years. The alternative of always wearing the seatbelt has the highest percentage with the age group over 55 years $(85.2 \%)$ and decreases with age, the lowest percentage being characteristic for the group in the $18-25$ age range (65\%). 
When answering the following question: "When you are accompanied, do your passengers wear the seatbelt?" the interviewed subjects (the drivers) had to choose one option out of four available closed-type questions.

After analyzing the data regarding wearing seatbelts by the passengers who accompany the driver (see Table 4), it was noticed that a higher percentage of women passengers wear the seatbelt, whether they occupy the front or the rear seats, in town or outside it $(8.1 \%$ and $17.4 \%)$, which shows that women are more responsible towards the passengers they are transporting.

Table 4. The wearing of seatbelts by car passengers, by driver gender and age.

\begin{tabular}{ccccc}
\hline & \multicolumn{4}{c}{ Fastening the Seatbelt by Passengers (\%) } \\
\hline Gender & $\begin{array}{c}\text { Yes, Only } \\
\text { the Front } \\
\text { Passenger }\end{array}$ & $\begin{array}{c}\text { Yes, the Front Passenger and } \\
\text { Those from the Rear Seats, Only } \\
\text { When Driving Outside the City. }\end{array}$ & $\begin{array}{c}\text { Yes, the Front Passenger and } \\
\text { Those from the Rear Seats in } \\
\text { the CIty and Outside It }\end{array}$ & No. \\
\hline men & 71.1 & 7.3 & 14.8 & 6.7 \\
women & 66.8 & 8.1 & 17.4 & 7.7 \\
Total & 70.3 & 7.5 & 15.3 & 6.9 \\
\hline Age: & & & & 7.6 \\
\hline 18-25 years & 77.0 & 4.7 & 14.5 & 7.7 \\
26-35 years & 70.5 & 7.3 & 18.2 & 6.0 \\
36-45 years & 65.9 & 9.8 & 15.7 & 5.6 \\
46-55 years & 72.4 & 6.3 & 21.7 & 2.3 \\
over 55years & 68.4 & 7.6 & 15.3 & 6.9 \\
Total & 70.3 & 7.5 & & \\
\hline
\end{tabular}

It can be seen that the passengers of young drivers, from the age group 18-25 years do not wear the seatbelt to a greater extent $(10.7 \%)$, which decreases with age. Seatbelt wearing only by the front seat passenger has a relatively constant weight for all age groups, between $65.9 \%$ and $77 \%$.

Analyzing the data regarding penalizing drivers for not using the seatbelt when driving (see Table 5), it can be noticed that the percentage of women drivers who were not punished for not using the seatbelt is higher, $81.6 \%$, as compared to the percentage of male drivers, $63.2 \%$, a situation correlated with the answers from the first question, where the percentage of women drivers wearing the seatbelt during driving is higher than that of male drivers. When looking at age groups, there are no large variations in the percentage of drivers penalized for not using the seatbelt, respectively, a minimum $24 \%$ for the category over 55 years and a maximum 36.9\% for the category 26-35 years. Results show that drivers aged 26 to 35 years have the highest percentage of not wearing the seatbelt and the drivers over 55 have the highest percentage for wearing it.

Table 5. Fining drivers for not using the seatbelt by driver gender and age.

\begin{tabular}{ccc}
\hline & As a Driver, Have You Ever Been Penalized/Received a Fine for not Using the Belt?(\%) \\
\cline { 2 - 3 } & Yes & No \\
\hline Gender: & & \\
\hline men & 36.8 & 63.2 \\
women & 18.4 & 81.6 \\
Total & 33.4 & 66.6 \\
\hline Age: & & \\
\hline 18-25 years & 29.4 & 70.6 \\
26-35 years & 36.9 & 63.1 \\
36-45 years & 36.2 & 63.8 \\
46-55 years & 31.3 & 68.7 \\
over 55 years & 24.0 & 76.0 \\
Total & 33.4 & 66.6 \\
\hline
\end{tabular}


The most common situation when the seatbelt is not worn is linked to travelling short distances $(\leqslant 25 \mathrm{~km})$. Six-hundred drivers $(72.1 \%$ of the respondents) stated that they do not wear the seatbelt when driving if trips are short, and $30.4 \%$ of the respondents do not wear the seatbelt while travelling within the city. For the total number of nominations for this issue, only $4.6 \%$ mentioned the travel at a speed lower than $50 \mathrm{~km} / \mathrm{h}$. Other situations when people do not use the seatbelt when travelling were mentioned as "when I am in a hurry/when I forget" - 26 nominations, "I am a taxi driver"-15 nominations, "for medical reasons"—six nominations, "when I drive the company's car" - four nominations, "during pregnancy"—four nominations, "when I am smartly dressed"-four nominations, "when I am uncomfortable" - 4 nominations, "when the road is very bad"- 3 nominations, "when there is the traffic jam", "when exercising the profession of driving instructor", "when I drive back" - one nomination for each situation (see Table 6). These results are obtained for the question "Which are the situations when you do not wear the seatbelt?". It is a semi-closed question, where the first three answer options are closed, and the fourth one opened, thus the interviewed subjects (drivers) have the opportunity to make more choices. The open answer option "other" has determined the results mentioned above.

Table 6. The situations in which drivers do not wear the seatbelt (multiple answers recorded) by driver gender and age.

\begin{tabular}{|c|c|c|c|c|}
\hline & \multicolumn{4}{|c|}{$\begin{array}{c}\text { The Situations in Which Drivers Do Not Wear the Seatbelt (Multiple } \\
\text { Answers Were Recorded) (\%) }\end{array}$} \\
\hline & $\begin{array}{l}\text { When I Drive } \\
\text { Short Distances }\end{array}$ & $\begin{array}{l}\text { When I Drive } \\
\text { in the City }\end{array}$ & $\begin{array}{l}\text { When the Speed Does } \\
\text { not Exceed } 50 \mathrm{~km} / \mathrm{h}\end{array}$ & Other \\
\hline \multicolumn{5}{|l|}{ Gender: } \\
\hline men & 51.9 (N 503) & 22.8 (N 221) & 4.1 (N 40) & $6.3(\mathrm{~N} 61)$ \\
\hline women & 9.8 (N 95) & 3.3 (N 32) & 0.5 (N 5) & 1.3 (N 12) \\
\hline Total & 61.7 (N 598) & 26.1 (N 253) & $4.6(\mathrm{~N} 45)$ & $7.6(\mathrm{~N} \mathrm{73})$ \\
\hline \multicolumn{5}{|l|}{ Age: } \\
\hline 18-25 years & 12.4 (N 120) & 5.7 (N 55) & 0.7 (N 7) & $1.2(\mathrm{~N} 12)$ \\
\hline 26-35 years & 21.9 (N 212) & $9.1(\mathrm{~N} 88)$ & 1.7 (N 16) & $2.5(\mathrm{~N} 24)$ \\
\hline $36-45$ years & 18.2 (N 177) & 7.1 (N 69) & $1.6(\mathrm{~N} 16)$ & 1.9 (N 18) \\
\hline 46-55 years & $6.3(\mathrm{~N} 61)$ & 2.9 (N 28) & $0.4(\mathrm{~N} 4)$ & 1.7 (N 16) \\
\hline over 55 years & 2.9 (N 28) & 1.3 (N 13) & $0.2(\mathrm{~N} 2)$ & 0.3 (N 3) \\
\hline Total & 61.7 (N 598) & 26.1 (N 253) & 4.6 (N 45) & 7.6 (N 73) \\
\hline
\end{tabular}

The reasons which influence drivers' behavior for not wearing the seatbelt were also analyzed. This question was answered by all those who do not always wear the seatbelt when driving, 900 persons, respectively (see Table 7). The logic diagram of the questionnaire has imposed that only those respondents who never wear the seatbelt to answer this question.

Table 7. The reasons which made drivers not wear the seatbelt (multiple choice questions).

\begin{tabular}{cccc}
\hline & $\begin{array}{c}\text { Nominal } \\
\text { Values }\end{array}$ & $\begin{array}{c}\text { Percentage Values (Relative to } \\
\text { the Number of Nominations) }\end{array}$ & $\begin{array}{c}\text { Percentage Values (Relative to } \\
\text { the Number of Respondents) }\end{array}$ \\
\hline $\begin{array}{c}\text { On short distances, I do not consider it } \\
\text { necessary to wear the belt. }\end{array}$ & 513 & $42.0 \%$ & $57.0 \%$ \\
\hline $\begin{array}{c}\text { In the city, I do not consider it necessary to } \\
\text { wear the belt. }\end{array}$ & 220 & $18.0 \%$ & $24.5 \%$ \\
\hline The belt disturbs me. & 190 & $15.6 \%$ & $21.1 \%$ \\
\hline I drive carefully, at a low speed. & 112 & $9.2 \%$ & $12.4 \%$ \\
\hline I am an experienced driver. & 49 & $4.0 \%$ & $5.5 \%$ \\
\hline I am not convince of the utility of the belt. & 30 & $2.5 \%$ & $3.3 \%$ \\
\hline I do not want to be trapped in case of a crash. & 29 & $2.4 \%$ & $3.2 \%$ \\
\hline Other & 77 & $6.3 \%$ & $8.5 \%$ \\
\hline Total & 1220 & $100 \%$ & - \\
\hline
\end{tabular}


The question "Please specify the reasons which determine you not to wear the seatbelt" is a semi-closed type having seven closed option answers and one opened.

It can be noticed that $57 \%$ out of the 900 respondents who do not always wear the seatbelt consider that, on short distances, it is not necessary to wear it, while $24.5 \%$ of them consider that within the city the seatbelt should not be worn. $21.1 \%$ of them mentioned that the seatbelt makes them feel uncomfortable while traveling, and 3.3\% of them are not convinced about the utility of wearing it. At the open option answer "other" reasons mentioned by the respondents for not wearing the seatbelt are: "I forget to fasten the seatbelt/from negligence" - 47 nominations, "it is not compulsory for taxi drivers" - 12 nominations, "health problems" —nine nominations, "I am pregnant"—six nominations, "convenience", "the car is not equipped with a seatbelt", "I am a driving instructor", and "I do not wear the seatbelt while doing my job"—one nomination each.

\section{Discussion}

The objective of this article was to identify the behavior of traffic participants from Romania regarding seatbelt wearing while driving vehicles. The results of this study, the first one at the national level, show that drivers from Romania have a seatbelt wearing behavior similar those from other countries, a fact confirmed by studies of researchers from different countries [30,36]. It can be noticed that, in Romania, too, women drivers wear the seatbelt to a higher extent than men, irrespective of age; the results obtained being in accordance with the previous studies conducted in France [36], USA [28,30], China [37], and Malaysia [26]. This issue is valid in the case of teenagers from the USA [38]. Among high school students from the USA, the percentage of women drivers wearing the seatbelt when driving is higher (66.7\%) than men (52.1\%) [39].

The study reveals the fact that young drivers from Romania are more prone not to wear seatbelts in comparison to older drivers. This confirms the results of research performed in other countries [30,38,40]. Vachal and Malchose [40] have demonstrated that not fastening the seatbelt favors the increase of the mortality hazard or the serious injury of young drivers in case of accidents at a percentage of $165 \%$.

Although the percentage of older people in the total number of the population is increasing and it is expected that road accidents with serious consequences will increase, a study conducted in the USA shows that the risk of accidents will decrease in the period 2000-2025 as a consequence of the increase in the number of persons wearing seatbelts [41]. These results are consistent with previous research, which show that older persons wear the seatbelt to a higher extent than young people. At the same time, drivers and all other passengers fasten seatbelts to a greater extent as they become older [36].

Differences were also revealed between the use of the seatbelt by passengers who travel on the front seat and those who travel on the rear seats [37]. The results of the present research outline the relatively low percentage of car drivers accompanied by passengers who do not wear the seatbelt, $6.9 \%$, and the fact that in the majority of the cases, $70.3 \%$ respectively, the only passengers who fasten their seatbelt are those who travel on the front seat. Milder et al. [42] show that the presence of a passenger in the vehicle triggers the use of the seatbelt to a higher extent, the main reason being the increase of the safety degree in the traffic. The other passengers use the seatbelt occasionally, usually when it involves car journeys outside the cities. According to the research findings, most car passengers who do not wear the seatbelt are those who travel with a young male driver. Similar studies have proved the low percentage of seatbelt use by passengers in the vehicle [43]. The results of the research presented in the article have emphasized the fact that in Romania, the highest percentage of situations when passengers do not wear the seatbelt, $10.7 \%$ respectively, is recorded in case of young car drivers in the 18-25 age range, followed by car drivers aged 26-35, the percentage of passengers not wearing the seatbelt being in this case $7.7 \%$. A study conducted in Malaysia shows that $48.2 \%$ of the drivers do not wear the seatbelt when there are passengers on the rear seat and that mlae passengers who travel as passengers in the rear seat have a higher tendency not to wear the seatbelt [26]. Hoe et al. [44] show that, in Egypt, the degree to which children use the seatbelt is low. Another study made in Utah, USA 
shows that children passengers who travel with drivers wearing the seatbelt are more inclined to wear the seatbelt, and drivers who wear the seatbelt are less involved in accidents with serious injuries [45].

This article analyzed the elements which were detailed to a lesser extent in previous studies. The first aspect refers to the identification of the percentage of car drivers penalized for not wearing the seatbelt. The percentages shown are high: $33.4 \%$ of the subjects being fined at least once for this reason; over this average there are car drivers aged 26-45 years, the percentage being reduced in case of those older than 55, 24\% respectively. Although fined, an important number of subjects, 1220 persons (respectively $28.1 \%$ of the total sample) declare that they do not wear the seatbelt in traffic at all.

A second relevant aspect is highlighting the most frequent situations when the drivers wear or do no wear the seatbelt. There was also a difference between those wearing or not wearing the seatbelt when taking into account the frequency of wearing it. Thus, $15.2 \%$ wear it "often" and $11.5 \%$ wear it only "sometimes". Out of the respondents who do not wear the seatbelt while travelling on short distances and when driving within the cities, $81.5 \%$ of respondents consider there are moments in traffic when it is not necessary to use the seatbelt. From the research conducted it results that Romanian drivers tend to believe that long distance travelling involves a higher accident risk, the propensity for fastening the seatbelt increases, while driving on short distances or within cities is perceived as less risky. Additionally, driving at a low speed, the experience in traffic, or the assessment regarding the uselessness of the seatbelt are other issues that justify the behavior of those who do not wear the seatbelt in traffic. Similar behaviors regarding not wearing the seatbelt within the cities were identified among car drivers from Turkey, a fact justified by perceiving traveling by car in town as having a lower risk [29]. A high degree of risk is represented by driving vehicles outside the city, by night, or in given conditions of unfavorable weather, situations in which the probability of wearing the seatbelt increases [29]. The findings do not apply in every instance. In France, driving vehicles during the night favors road accidents, as drivers tend to increase speed, while the probability of fastening the seatbelt decreases [36].

The results identified are significant in terms of emphasizing the behavior of Romanian car drivers in traffic regarding the habit of using the seatbelt. The issues presented can be used by the Romanian Police for managing the moments and places for controls, for improving and adapting the legislation in effect, for coordinating all road accident preventive measures, and for convincing the population about the utility and obligation for fastening the seatbelt. Furthermore, the companies producing such equipment can use the results presented to improve the comfort of wearing the seatbelt. It was noticed that one of the reasons for not fastening the seatbelt is the possibility of the person blocked in the case of an accident, which can worsen the state of the person injured. The continuous application of the social marketing techniques taken over within the discipline "road safety marketing" can influence the behavior of traffic participants by changing it for the better.

\section{Conclusions}

Following this study, it was highlighted that drivers' behavior in Romania regarding seatbelt wearing depends on gender and age, resulting that this behavior largely falls in the general behavior of drivers all over the world, as shown in different studies [26,30,37].

It can be concluded that young male drivers have the tendency not to wear the seatbelt when driving the vehicle and that their passengers do not use the seatbelt to a large extent. These results are correlated with the answers of the drivers who confirm having been fined in a higher percentage for not wearing the seatbelt. Additionally, women drivers and medium-age respondents wear the seatbelt to a higher extent when driving [43]. The research also shows that numerous drivers do not consider it necessary to wear the seatbelt when driving within the city or on short distances.

The results obtained were made available to the Romanian Police and were the basis of specific measures included in the new Road Code in Romania, which entered into force in 2015. The new Road Code includes the increase of fines for not wearing the seatbelt, because in the previous period the low level of fines did not determine a behavioral change of the drivers and passengers in the desired 
direction. Although it seems to be a coercive measure, it is not in contradiction with laws in force in Romania and it is hoped to obtain positive social-economic results together with the behavioral change. Specialized companies are now conducting studies for improving seatbelts, thus making the risk of injuring drivers and passengers as low as possible [46]. The European Automotive Industry has already taken some measures towards corporate sustainability, measures which also include policies designed to improve safety performance [47].

In this framework, the opportunity of tougher sanctions is shown for those who do not wear the seatbelt in traffic, drivers and passengers, contributing to the reduction of the accidents' undesirable effects on national roads: deaths, injured people in different stages of severity who need different days of hospitalization and recovery, which means inactivity in the labor market with negative social economic implications for the country. Legal regulations and controls made by the police influence the increase of seatbelt use to a great extent [42]. Furthermore, the changes in the administrative measures will create positive expected results if they are accompanied and completed by the application of the principles of road safety marketing, which represents a reference in developing and launching campaigns and road safety marketing programs, with a view of reducing road accidents and their negative effects.

Acknowledgments: We address special thanks to the company Profiles International and Romanian Police for supporting us for the field data collection.

Author Contributions: All the authors had equal contributions to this work, to research design and analysis. All authors read and approved the final manuscript.

Conflicts of Interest: The authors declare no conflict of interest.

\section{Abbreviations}

The following abbreviations are used in this manuscript:

ETSC European Transports Safety Council

\section{References}

1. Nicolăescu, E.; Alpopi, C.; Zaharia, C. Measuring Corporate Sustainability Performance. Sustainability 2015, 7, 851-865. [CrossRef]

2. De Pauw, J.B.; Gericke, N.; Olsson, D.; Berglund, T. The Effectiveness of Education for Sustainable Development. Sustainability 2015, 7, 15693-15717. [CrossRef]

3. Cioca, L.I.; Ivascu, L.; Rada, E.C.; Torretta, V.; Ionescu, G. Sustainable Development and Technological Impact on $\mathrm{CO}_{2}$ Reducing Conditions in Romania. Sustainability 2015, 7, 1637-1650. [CrossRef]

4. Nakanishi, H.; Black, J. Social Sustainability Issues and Older Adults' Dependence on Automobiles in Low-Density Environments. Sustainability 2015, 7, 7289-7309. [CrossRef]

5. Jou, R.-C.; Chen, T.-Y. External Costs to Parties Involved in Highway Traffic Accidents: The Perspective of Highway Users. Sustainability 2015, 7, 7310-7332. [CrossRef]

6. Carnis, L.; Blais, E. An assessment of the safety effects of the French speed camera program. Accid. Anal. Prev. 2013, 51, 301-309. [CrossRef] [PubMed]

7. Siskind, V.; Steinhardt, D.; Sheehan, M.; O'Connor, T.; Hanks, H. Risk factors for fatal crashes in rural Australia. Accid. Anal. Prev. 2011, 43, 1082-1088. [CrossRef] [PubMed]

8. Jost, G.; Allsop, R.; Steriu, M.; Popolizio, M. 2010 Road Safety Target Outcome: 100,000 Fewer Deaths Since 2001. 5th Road Safety Pin Report. Available online: http://archive.etsc.eu/documents/ETSC_2011_ PIN_Report.PDF (accessed on 30 September 2015).

9. European Commission. Press Release. Available online: http://europa.eu/rapid/press-release_IP-14-341_ en.htm (accessed on 20 August 2015).

10. European Commission. The Report of the Year 2014 Regarding Deaths on European Roads. Available online: http://ec.europa.eu/romania/news/articole_si_dialoguri/26032015_raport_decese_sosea_ro.htm (accessed on 20 August 2015). 
11. UN Road Safety Week 2015—“Save Kids Lives"—What the EU can do. Available online: http://etsc.eu/unroad-safety-week-2015-save-kids-lives-what-the-eu-can-do/ (accessed on 21 July 2015).

12. National Institute of Statistics. TEMPO Online. Available online: http://statistici.insse.ro/shop/ index.jsp?page $=$ tempo2\&lang=en\&context=56 (accessed on 10 December 2015).

13. New Road Code. Available online: http://legislatie.autoraid.ro/noul_cod_rutier.html (accessed on 10 September 2015).

14. Chiou, Y.C.; Lan, L.W.; Chen, W.P. A two-stage mining framework to explore key risk conditions on one-vehicle crash severity. Accid. Anal. Prev. 2013, 50, 405-415. [CrossRef] [PubMed]

15. Huang, Y.H.; Zhang, W.; Murphy, L.; Shi, G.; Lin, Y. Attitudes and behavior of Chinese drivers regarding seatbelt use. Accid. Anal. Prev. 2011, 43, 889-897. [CrossRef] [PubMed]

16. Reagan, I.J.; McClafferty, J.A.; Berlin, S.P.; Hankey, J.M. Using naturalistic driving data to identify variables associated with infrequent, occasional, and consistent seat belt use. Accid. Anal. Prev. 2013, 50, 600-607. [CrossRef] [PubMed]

17. Sobhani, A.; Young, W.; Logan, D.; Bahrololoom, S. A kinetic energy model of two-vehicle crash injury severity. Accid. Anal. Prev. 2011, 43, 741-754. [CrossRef] [PubMed]

18. Strine, T.W.; Beck, L.F.; Bolen, J.; Okoro, C.; Dhingra, S.; Balluz, L. Geographic and socio-demographic variation in self-reported seat belt use in the United States. Accid. Anal. Prev. 2010, 42, 1066-1071. [CrossRef] [PubMed]

19. Bilban, M.; Zaletel-Kragelj, L. Seat-belt use and non-use at adults in Slovenia. Int. J. Public Health 2007, 52, 317-325. [CrossRef] [PubMed]

20. Pakgohar, A.; Tabrizi, R.Z.; Khalili, M.; Esmaeili, A. The role of human factor in incidence and severity of road crashes based on the CART and LR regression: A data mining approach. Procedia Comput. Sci. 2011, 3, 764-769. [CrossRef]

21. European Transport Safety Council. New Survey Reveals Many Europeans Still don't Take Seatbelt Laws Seriously. Available online: http:/ / etsc.eu/new-survey-reveals-many-europeans-still-dont-take-seatbeltlaws-seriously/ (accessed on 22 August 2015).

22. Şimşekoğlu, O.; Lajunen, T. Relationship of seat belt use to health and driver behaviors. Transp. Res. F 2009, 12, 235-241. [CrossRef]

23. Staff, T.; Eken, T.; Hansen, T.B.; Steen, P.A.; Sovik, S. A field evaluation of real-life motor vehicle accidents: Presence of unrestrained objects and their association with distribution and severity of patient injuries. Accid. Anal. Prev. 2012, 45, 529-538. [CrossRef] [PubMed]

24. Blincoe, L.J.; Seay, A.; Zaloshnja, E.; Miller, T.; Romano, E.; Luchter, S. The impact of a standard enforcement safety belt law on fatalities and hospital charges in Ohio. J. Saf. Res. 2010, 41, 17-23.

25. Funk, J.R.; Cormier, J.M.; Manoogian, S.J. Comparison of risk factors for cervical spine, head, serious, and fatal injury in rollover crashes. Accid. Anal. Prev. 2012, 45, 67-74. [CrossRef] [PubMed]

26. Ng, C.P.; Law, T.H.; Wong, S.V.; Kulanthayan, S. Factors related to seatbelt-wearing among rear-seat passengers in Malaysia. Accid. Anal. Prev. 2013, 50, 351-360. [CrossRef] [PubMed]

27. Fernandes, R.; Hatfield, J.; Soames, J.R. A systematic investigation of the differential predictors for speeding, drink-driving, driving while fatigued, and not wearing a seat belt, among young drivers. Transp. Res. F 2010, 13, 179-196. [CrossRef]

28. Gkritza, K.; Mannering, F.L. Mixed logit analysis of safety-belt use in single and multi-occupant vehicles. Accid. Anal. Prev. 2008, 40, 443-451. [CrossRef] [PubMed]

29. Şimşekoğlu, O.; Lajunen, T. Why Turks do not use seat belts? An interview study. Accid. Anal. Prev. 2008, 40, 470-478. [CrossRef] [PubMed]

30. Molnar, L.J.; Eby, D.W.; Dasgupta, K.; Yang, Y.; Nair, V.N.; Pollock, S.M. Explaining state-to-state differences in seat belt use: A multivariate analysis of cultural variables. Accid. Anal. Prev. 2012, 47, 78-86. [CrossRef] [PubMed]

31. Koppel, S.; Charlton, J.; Fildes, B.; Fitzharris, M. How important is vehicle safety in the new vehicle purchase process? Accid. Anal. Prev. 2008, 40, 994-1004. [CrossRef] [PubMed]

32. Schultz, P.W. Conservation means behavior. Conserv. Biol. 2011, 25, 1080-1083. [CrossRef] [PubMed]

33. Schroer, A.L.; Lowman, H.E.; Just, C.L. Educating the Aware, Informed and Action-Oriented Sustainable Citizen. Sustainability 2015, 7, 1985-1999. [CrossRef] 
34. European Road Safety Charter. Available online: http://www.cisr.ro/document_1465_Carta-Europeana-aSigurantei-Rutiere_pg_0.htm (accessed on 22 August 2015).

35. Road Agenda. Available online: http://www.agendarutiera.ro/agendarutiera-ro_doc_1_despre-calendarulevenimentelor-de-siguranta-rutiera_pg_0.htm (accessed on 12 September 2015).

36. De Lapparent, M. Willingness to use safety belt and levels of injury in car accidents. Accid. Anal. Prev. 2008, 40, 1023-1032. [CrossRef] [PubMed]

37. Routley, V.; Ozanne-Smith, J.; Qin, Y.; Wu, M. Taxi driver seat belt wearing in Nanjing, China. Accid. Anal. Prev. 2009, 40, 449-454. [CrossRef] [PubMed]

38. Kim, S.; Depue, L.; Spence, L.G.; Reine, J. Analysis of teenage seat belt use: From the 2007 Missouri high school seat belt survey. J. Saf. Res. 2009, 40, 311-316. [CrossRef] [PubMed]

39. Briggs, N.C.; Lambert, W.; Goldzweig, I.A.; Levine, R.S.; Warren, R.C. Driver and Passenger Seatbelt Use Among U.S. High School Students. Am. J. Prev. Med. 2008, 35, 224-229. [CrossRef] [PubMed]

40. Vachal, K.; Malchose, D. What can we learn about North Dakota's youngest drivers from their crashes? Accid. Anal. Prev. 2009, 41, 617-623. [CrossRef] [PubMed]

41. Cheung, I.; McCartt, A.T. Declines in fatal crashes of older drivers: Changes in crash risk and survivability. Accid. Anal. Prev. 2011, 43, 666-674. [CrossRef] [PubMed]

42. Milder, C.M.; Gupta, S.; Ozkan, T.; Hoe, C.; Lajunen, T. Predictors of intrinsic motivation behind seatbelt use in a country where current use is law. Injury 2013, 44, 557-563. [CrossRef]

43. Vecino-Ortiz, A.I.; Bishai, D.; Chandran, A.; Bhalla, K.; Bachani, A.M.; Gupta, S.; Slyunkina, E.; Hyder, A.A. Seatbelt wearing rates in middle income countries: A cross-country analysis. Accid. Anal. Prev. 2014, 71, 115-119. [CrossRef] [PubMed]

44. Hoe, C.; Puvanachandra, P.; Rahman, M.H.; El Sayed, H.; Eldawy, I.; El-Dabaa, A.; Albert, M.; Hyder, A.A. Seatbelt use and speeding on three major roads in Egypt: A brief report. Injury 2013, 44, 545-548. [CrossRef]

45. Olsen, C.S.; Cook, L.J.; Keenan, H.T.; Olson, L.M. Driver seat belt use indicates decreased risk for child passengers in a motor vehicle crash. Accid. Anal. Prev. 2010, 42, 771-777. [CrossRef] [PubMed]

46. Automotive Engineer. Autoliv reduces injury risk with additional seatbelts. June 2012. Available online: http:/ / connection.ebscohost.com/c/articles/77390643/autoliv-reduces-injury-risk-additional-seatbelts (accessed on 4 March 2014).

47. Sukitsch, M.; Engert, S.; Baumgartner, R.J. The Implementation of Corporate Sustainability in the European Automotive Industry: An Analysis of Sustainability Reports. Sustainability 2015, 7, 11504-11531. [CrossRef]

(C) 2016 by the authors; licensee MDPI, Basel, Switzerland. This article is an open access article distributed under the terms and conditions of the Creative Commons by Attribution (CC-BY) license (http:/ / creativecommons.org/licenses/by/4.0/). 